UDK 876.2 Krek g. Špela Tršinar

Bratovševa ploščad 14,

SI-1000 Ljubljana

\title{
KOMPOZICIJSKI STAVEK KLAVIRSKIH DEL GOJMIRJA KREKA*
}

\section{The Compositional Technique in G. Krek's Piano Works}

\section{POVZeteK}

Na Slovenskem se je začela klavirska glasba razvijati sicer že v začetku 19. stoletja, vendar pa pomenijo prvi pravi premik šele Novi akordi, katerih urednik Gojmir Krek si je še posebej prizadeval za izboljšanje instrumentalne in s tem tudi klavirske glasbe. Z razmeroma obsežnim klavirskim opusom je k slovenski klavirski glasbi prispeval tudi sam. Posamična glasbena dela znotraj le-tega tudi pomenijo pomembno razvojno stopnjo slovenske klavirske glasbe. Vendar pa analitični prerez pokaže, da skladatelj v glasbeni praksi ni znal ali ni mogel uresničiti svojih v publicistiki deklariranih "modernih" naziranj, ki so v glasbi sicer nakazana, a nikoli do konca uresničena. Tako melodika kot harmonija, pa tudi oblikotvorni postopek kažejo skladateljevo trdno navezanost na klasicistično in romantično tradicijo, s katero ne prekine niti v poznem ustvarjalnem obdobju. Zato mu gre pripisati vlogo ključnega razvojnega člena $v$ slovenski glasbi v prvi vrsti kot teoretiku, glasbenemu piscu in kritiku.

\begin{abstract}
SUMMARY
Although Slovenian piano music began to develop in the early $19^{\text {th }}$ century, the first turning point came only with the New Chords magazine (Novi akordi, 1901-14). Its editor, Gojmir Krek, made every effort to improve the level of instrumental, and therefore also - piano music. He himself contributed a relatively large number of works to Slovenian piano music, some of which represent an important stage in its development. However, as analysis has proven, Krek as a composer was not able to or did not know how to realize in practice, i.e. in his own music, all those declarations of "modernism" he drafted and wrote about in his periodical. It is true that such ideas can be detected in his music, though never in a accomplished way. His melodic, harmonic and formal procedures speak of his deep attachment to the classical and romantic tradition, present also in his later compositions. Therefore, he should be praised for his unique contribution to Slovenian music, first and foremost, as a theorist and a music critic.
\end{abstract}

\footnotetext{
* Vsebina prispevka je povzeta po diplomski nalogi, ki je nastala pod mentorstvom doc. dr. Aleša Nagodeta na Oddelku za muzikologijo Filozofske fakultete v Ljubljani.
} 
Na Slovenskem se je začela klavirska glasba razvijati sicer že v začetku 19. stoletja, vendar so bile to preproste skladbe, ki so zadostovale potrebam in zahtevam takratnega meščanstva. Tako so prevladovali nemški plesi, valčki, polke, koračnice, prebudniške skladbe in skladbe, napisane po ljudskih napevih. Tudi skladateljev, ki bi obvladali kompozicijsko tehniko klavirskega stavka, je bilo malo. Po letu 1848 je težnja po višji kakovosti slovenske glasbe rasla predvsem na področju vokalne glasbe, ki je bila tedanjemu Slovencu bližja kot klavirska in instrumentalna nasploh. Spremembe so prinesle šele prve revije ${ }^{1}$, ki so omogočile redno tiskanje glasbenih del in s tem postopno tudi večjo produktivno silo.

Pravi premik v slovenski klavirski glasbi pa so prinesli Novi akordi, katerih urednik Gojmir Krek si je še posebej prizadeval za izboljšanje instrumentalne glasbe. Po njegovem mnenju je bil glavni vzrok nezanimanja za klavirsko glasbo v prvi vrsti slovenski narod kot narod petja, nenazadnje pa je med Slovenci še vedno primanjkovalo veščih pianistov. Zato tudi takratni skladateljski element tej glasbeni zvrsti ni posvečal večje pozornosti. S poznavanjem aktualne problematike $\mathrm{v}$ slovenski glasbi in s postopnim uresničevanjem svojih naprednih idej pa je Krek spodbudno vplival na skladateljsko in izvajalsko prakso v klavirski glasbi.

$Z$ razmeroma obsežnim klavirskim opusom, razdeljenim $\mathrm{v}$ dve daljši obdobji, je $\mathrm{k}$ slovenski klavirski glasbi prispeval tudi Krek sam. Prvo obdobje je čas, ko je bil Krek urednik Novih akordov (1901-1914). To obdobje sicer ne obsega večjega števila klavirskih del, a je razvojno pomembno. Vse skladbe, nastale $v$ tem času (torej v letih od 1901 do 1914), so bile $\mathrm{v}$ glasbeni reviji tudi natisnjene, seveda tudi in predvsem po zaslugi skladatelja samega, saj je kot urednik revije vplival na izbor natisnjenih skladb. Večinoma gre za preprostejša in krajša dela, ki so pomenila velik napredek v primerjavi z že obstoječo klavirsko literaturo na Slovenskem. Skladbe, vsega skupaj jih je 11, so večinoma plesnega značaja in tehnično že razmeroma zahtevne.

$S$ prenehanjem izhajanja Novih akordov je zamrla tudi Krekova ustvarjalnost. Vzrokov za to je več, med drugimi tudi prva svetovna vojna in poklicne - pravniške obveznosti skladatelja, katerega skladateljska dejavnost je zaživela zopet šele v tridesetih letih, natančneje leta 1935. Značilno je, da so vse skladbe povojnega obdobja oštevilčene $z$ opusi (prva klavirska skladba je Valček, op. 4), medtem ko dela iz Novih akordov teh oznak nimajo. Skladbe so večinoma daljše, najpogosteje s programskimi naslovi, značilni pa so tudi daljši ciklusi: na primer Domače epizode, op. 29/1-4; Iz potne torbe, op. 38/1-5; Iz naših logov, op. 55/1-4; Jugoslovanski plesi, op. 56/1-3 ter Jugoslovanski plesi, op. 61/4-8.

Drugo obdobje je številčno obsežnejše, saj prinaša kar 42 klavirskih del. Vendar pa je bila natisnjena le peščica vseh, natančneje $8 .^{2}$ Vzrok za to je potrebno iskati predvsem v vse manjši aktualnosti Kreka kot skladatelja in tudi teoretika. Povojna leta so prinesla v slovensko glasbo nove stilne smernice, za katere so se zavzemali predvsem skladatelji mlajše generacije. Krek jim ni sledil. Postal je za tisti čas konzervativen, zato tudi vedno manj zanimiv.

Pri obravnavi Krekovih glasbenih, v tem primeru klavirskih del, analitik ne more mimo skladateljevih teoretskih idej in razmišljanj, predstavljenih v Novih akordih. Pri tem se samo postavlja vprašanje, kako uspešno je Krek v publicistiki deklarirana moderna naziranja realiziral v melodiki, harmonski zasnovi in nenazadnje v oblikovanju svojega klavirskega opusa. Analitični prerez pa pokaže, da skladatelj v glasbeni praksi ni znal ali ni mogel uresničiti vseh svojih idej in stremenj za naprednim v glasbi. Njegove skladbe ostajajo zato navezane na tradicijo, saj je kot skladatelj nihal med klasicistično prakso in romantičnim hotenjem.

\footnotetext{
${ }_{1}$ Cerkveni glasbenik 1878; Glasbena zora 1899.

${ }^{2}$ Vse razen skladbe Jesen op. 59, ki je bila izdana 1938. leta v reviji Zvonček, je izdala Glasbena matica leta 1944, po skladateljevi smrti.
} 
Krekov klavirski opus prežema liričen izraz. Njegove melodije so jasne in navadno ne širšega obsega. Preveva jih romantično občutenje, čeprav nikoli ne dosežejo večjega emotivnega naboja. Močan intelekt je vseskozi zaviral skladateljevo globljo izpovednost. Melodika se tako giblje v ozkem pasu izraznih možnosti liričnosti, vendar se skladatelj ne odreče kontrastom, ki pa ostajajo bolj nakazano kot doživeto čustvo. Liričnost glasbenih misli zaznamujeta prevladujoče postopno gibanje in valovanje melodičnega toka ter počasen tempo. Melodije so mirne in nežne ali umirjeno lahkotne, izpeljane pod širšim lokom.

Nasprotje liričnim so duhovite in iskrive, pogosto tudi karakterne glasbene misli, za katere se včasih zdi, da bolj ustrezajo skladateljevi strogo razumski drži. Te skladbe so lahko po izrazu vesele, žive, igrive ali impulzivne. Tempo je navadno zmeren do hiter, melodični tok pa je največkrat drobljen in prekinjen s pavzami.

Posebno eksplozivne in energične so idiomatične skladbe, $v$ katerih je v ospredju virtuoznost glasbenega poteka. Tu se kaže Krekovo poznavanje tehničnih zmožnosti instrumenta (in nenazadnje tudi pianista). Večina idiomatičnih skladb (tri od skupno štirih) pa je nastala $\mathrm{v}$ povojnem obdobju, zato ima pomembno razvojno vlogo $\mathrm{v}$ smislu tehnične zahtevnosti le ena: Slovanski capriccio (izdana v Novih akordih I, št. 1). (primer 1)

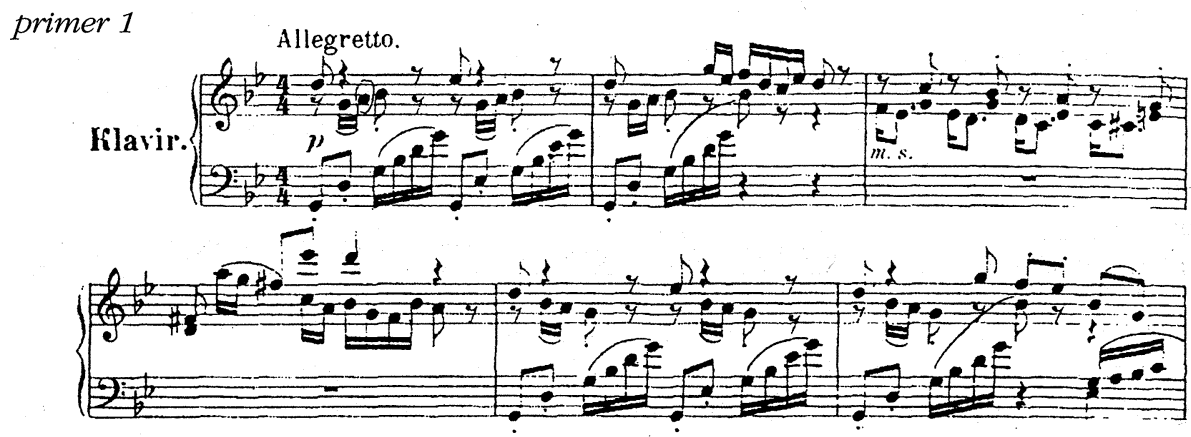

Pomembno mesto v opusu je Krek namenil plesnim skladbam, največkrat napisanih v smislu valčka ali ländlerja. Melodika teh skladb je večinoma lahkotna, preprosta in široko postavljena, navadno akordsko zasnovana. Osrednjo vlogo ima seveda ritmični pulz v spremljavi. Določene oblike pa so zaznamovane $z$ njej lastno ritmiko $v$ samem melodičnem poteku (na primer Mazurka, op. 66 in Polka française).

Večji del skladb ima določen pomenski naslov, ki pa ne pomeni programskega ozadja glasbe. Napoveduje le določeno razpoloženje, katerega je znal skladatelj kljub relativni preprostosti glasbenih misli prepričljivo prikazati. Zgleden primer je ciklus skladb $I z$ naših logov, kjer je "domačnost" glasbenih utrinkov dosegel med drugim tudi s črpanjem glasbene tematike iz slovenske ljudske pesmi: srednji B-del tretje skladbe ciklusa (primer 2) temelji na ljudski "Jaz pa pojdem na Gorenjsko."3

primer 2

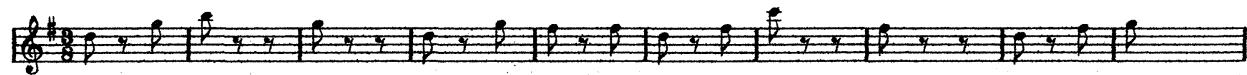

Glasbene misli navadno uokvirja periodična struktura, prevladuje pa simetričnost 8 (16)-taktne periode. Krek je pri tem dosleden; periode so namreč "pravilno" členjene s polkadenčnimi premori in zaključujejo z melodično kadenco, katere intenziteta je ved-

${ }^{3}$ Konkretni primeri ljudskih pesmi so vključeni že v skladbi Po ljubih potih. 
no dovolj občutena, navadno tonična, le redko se konča na III. stopnji ali dominanti. Melodija znotraj periodične strukture sloni na karakterističnem motivu, ki je najpogosteje enotakten, lahko pa tudi krajši. Na principu klasicistične gradnje slonijo tudi razširjene periode, katerih "nepravilnost" je posledica notranje in zunanje razširitve.

Le posamični primeri kažejo na drugačna odstopanja od simetrične strukture, ne pomenijo pa "rušenja" tradicionalnega: skrajšana perioda in verižno sosledje melodičnih misli. V Krekovem klavirskem opusu najdemo le en primer skrajšane periodične strukture, in sicer v B-delu skladbe Iz naših logov II, op. 55/2 (primer 3). Le-tu je v 7-taktni periodi ( $z$ dvostavčno gradnjo 4+3) skrajšan drugi stavek. Predvsem zaradi izrazite spevnosti melodčnega poteka bi bilo pričakovati širši kulminacijski lok, ki bi dopolnil enotaktno "praznino". Vendar pa je le-ta zaradi počasnega tempa primerna in učinkovita.

primer 3

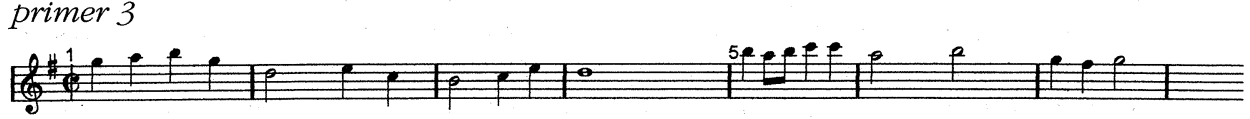

Primer skrajšane periode načeloma pomeni tudi veriga melodičnih linij (stavkov). Tudi te so pri Kreku redke. Jasen primer zasledimo v Humoreski, op. 43/3 (primer 4), v kateri sestoji 9-taktna melodična struktura iz dveh 5-taktnih stavkov v verižnem sosledju, saj je zaključni ton prvega hkrati tudi začetni ton drugega. Stavka sta simetrična, notranje razširjena, sorodnost med obema pa je očitna, saj gre le za modulacijsko spremembo.

primer 4

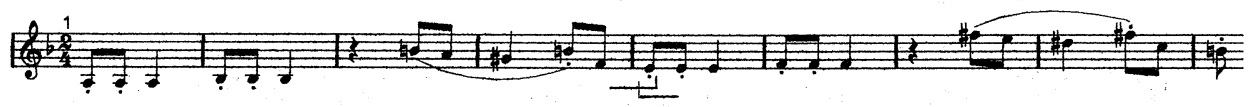

Strukturiranje melodike ni nujno vedno periodično. Skladatelj oblikuje izstopajoči glas razmeroma pogosto v obliki stavka. V kolikor bi se le-ta ponovil, bi bilo seveda oblikovanje zopet periodično. Pogosto njegove ponovitve ni, ali pa jo skladatelj variira in se tako oddalji od pričakovane kvadratičnosti. $V$ takih primerih je zato značilna melodična linija, uokvirjena $v$ stavčno strukturo različnih dolžin, ki je lahko še naprej (simetrično oziroma asimetrično) členjena, navadno pa gre za krajše tematske stavke.

Le redko tvori glasbeni odsek dvotaktje kot samostojna celota. Delo z dvotaktji je namreč značilno v kontrastnih atematskih delih, saj znotraj dveh taktov ne gre za izrazite melodične linije, so pa razpoznavni določeni motivični elementi: na primer Jugoslovanski ples II, op. 56/2 (primer 5).

\section{primer 5}

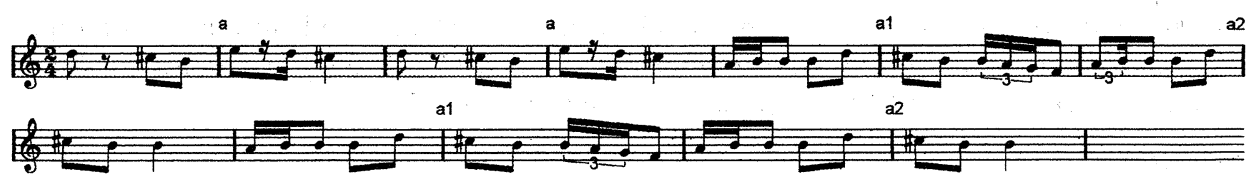

Poleg že omenjenega je značilna še sekvenčna gradnja, ko postavi skladatelj v začetku glasbenega odseka razpoznavno melodično linijo različnih dimenzij in jo nato sekvenčno ponavlja, transponira, variira.

$\mathrm{V}$ tako značilnem postopku oblikovanja izstopata kot osamljena primera skladbi Noveleta, op. 45 (primer G) in Žuželke v poletnem soncu, op. 24 . V prvi je značilna variacijska gradnja, saj je celotni A-del skladbe osnovan na uvodnem 4-taktju. Vsak nov nastop 
te tematske strukture napove vedno nespremenjen uvodni takt. ${ }^{4}$ Glasbena misel je $\mathrm{z}$ vsakim nastopom tudi oblikovno ali ritmično spremenjena: lahko je notranje razširjena kot posledica kulminacije ali pa je variirana ritmično z "vrivkom" punktirane celice. Melodični tok je členjen s spremembami tempa, sicer pa se skladatelj vseskozi izogiba kadenčnim premorom. S tem skladatelj nakazuje na oblikovno načelo v smislu "neskončne" melodije wagnerjanskega tipa, katerega je (delno) uresničil v B-delu skladbe op. 24 (primer 7). V primeru slednje ne gre za neprekinjeno melodično linijo, temveč "le" za 12-taktni melodični lok, ki pa kot tak v opusu kljub vsemu izstopa. Glasbena struktura ni členjena ne harmonsko ne ritmično in niti ne s pomočjo sprememb tempa, tudi ponavljanj ni. Da bi tok ne bil prekinjen, tudi ni polkadenčnih premorov. Le-tem se najbolj izogiba s postopnimi ritmičnimi obogatitvami, s katerimi doseže glasbeni tok svoj višek.

primer 6

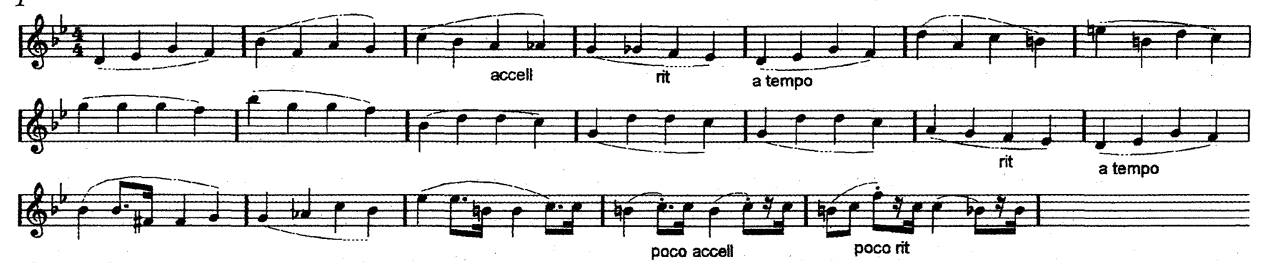

primer 7
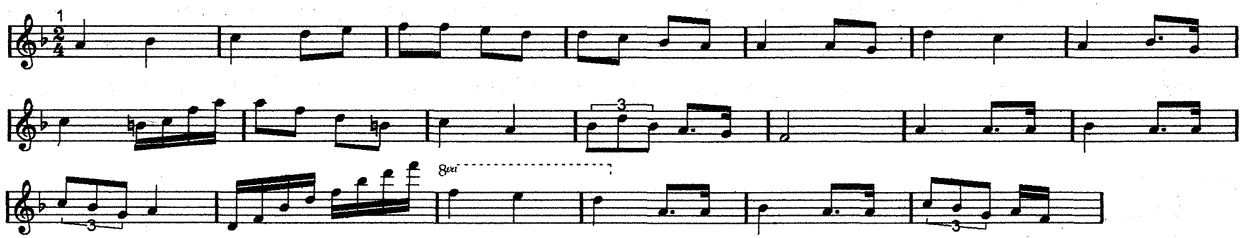

Melodika izhaja skoraj vedno iz harmonske spremljave, zato je najpogosteje akordska. Tudi tu se skladatelj nasloni na klasicistično estetiko, sicer pogosto zakrito s kromatičnimi, harmonsko tujimi toni. Le redko srečamo glasbene misli, katerih potek je neodvisen od harmonskega. Tako ali drugače zasnovana melodika je zaznamovana $z$ ustrezno ritmiko, ki je kot taka vedno v službi glasbenega izraza. Le-ta ne odloča le o njeni strukturi, pač pa tudi o njeni vlogi. Ritem je največkrat tekoč in umirjen, ritmične posebnosti (kot so binar v ternarju, kvintole, septole in redke spremembe taktovega načina) niso pogoste. Zato je redka tudi ritmična razgibanost $\mathrm{v}$ obravnavi tonskega gradiva: večjo diferenciranost ritmičnih figur prinese na primer ciklus skladb Iz potne torbe. Znotraj le-tega izstopa tretja skladba (primer 8), v kateri se v melodičnem poteku izmenjujeta binarna in ternarna delitev. Na drugi strani pa je prva skladba ciklusa (primer 9) edini primer horizontalne polimetrije $\mathrm{v}$ Krekovem klavirskem opusu.

primer 8

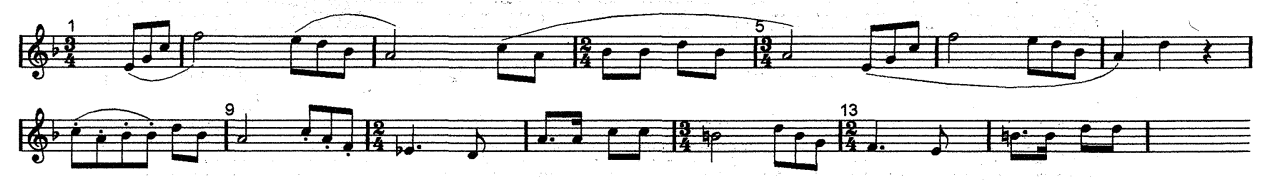

${ }^{4}$ Sorodnost sosledja štirih tonov z uvodnimi takti Chopinovega Valčka, op. 64/1 je presenetliva. 


\section{primer 9}

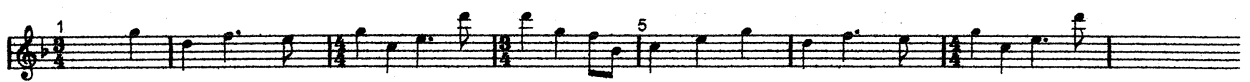

V gradnji melodike ostaja Krek torej predvsem tradicionalen. Odmiki so nakazani z razmeroma pogostimi kromatizmi, ki dajejo glasbeni misli za tisti čas vsekakor nov in svež ton. Bolj drzen pa je skladatelj v oblikovanju harmonskega stavka, kar pravzaprav ne preseneti, saj mu "neizmerno bogatejša [harmonija] pomeni glavno činiteljico moderne glasbe." In res je bil skladateljev harmonski stavek iz skladbe v skladbo bogatejši, po kompozicijskih sredstvih vedno raznovrstnejši, s pogosto poudarjeno kromatiko ali harmonsko tujimi toni. A tudi tu teoretskih idej Krek v praksi ni uresničil. Navezanost na klasicistično estetiko je bila $\mathrm{v}$ določenih trenutkih premočna in preveč ustrezna skladateljevemu glasbenemu mišljenju. Zato ostaja njegov kompozicijski stavek čist, v skladu s periodično gradnjo pa se v prvi vrsti kaže $\mathrm{v}$ trdno zaključenih in prepričljivih zaključnih kadencah posameznih period, večjih delov glasbene oblike in nenazadnje $v$ finalnih taktih. Odmiki v slednjih so še posebej redki in ne pomenijo "novo", pač pa le "manj dosledno". Zaključne kadence namreč prepričljivo zaključujejo glasbena dela, so stabilne in ne ustvarjajo potrebe po harmonskem, melodičnem ali ritmičnem nadaljevanju.

V opusu morda še najbolj presenetita kadenčna zaključka v skladbah Veselo obvestilo, op. 56 (primer 10) in Jugoslovanski ples I, op. 59/1. V primeru prvega se v finalnih taktih dominantni septakord povsem po pričakovanju razveže $\mathrm{v}$ tonični akord $\mathrm{v}$ oktavni legi in tu bi se skladba lahko prepričljivo končala. Vendar pa takoj sledi akord stranske dominante frigijskega akorda, ki zmoti jasnost harmonskega poteka. A se tok glasbe $\mathrm{z}$ naslednjim akordom vrne nazaj v tonični akord osnovne tonalitete, $s$ katerim skladba tudi zaključi. Tak hipni odmik od tonalitete je skladatelju potreben, da bi še potrdil zaključek.

primer 10

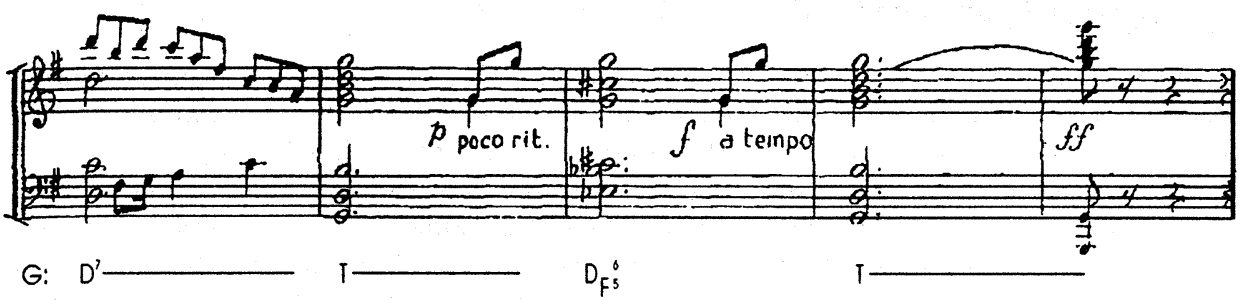

Preprost in nekoliko manj prepričljiv je zaključek v Jugoslovanskem plesu I (primer 11). Pedalna tonika, ležeča skozi celo 8-taktno periodo, je značilna vse do konca, zato basov (tonični) ton nima ostrine in intenzitete, pričakovane $v$ zaključnem toničnem akordu osnovne tonalitete. Le-ta tudi ni popoln, saj manjka kvinta. Zato zaključek skladbe "obvisi v zraku", deluje odprto in nepopolno.

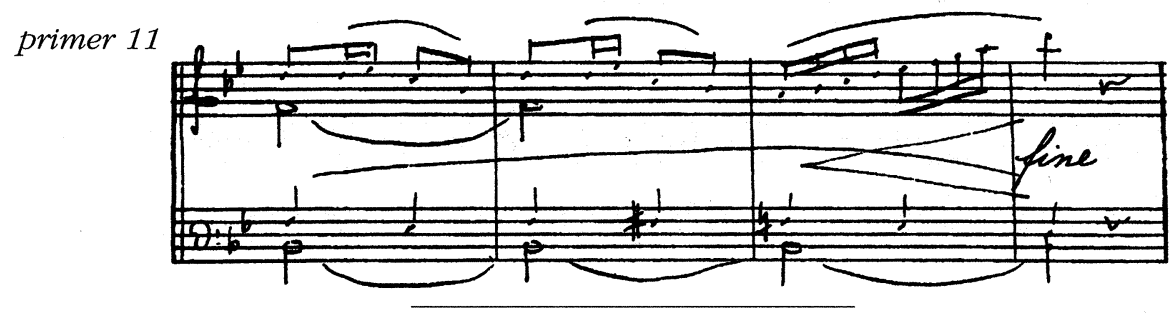

s Prim. Gojmir Krek, ur. Dragotin Cvetko (Ljubljana, Partizanska založba 1988), str. 176. 
Navezanost na tradicijo se kaže tudi v izbiri tonalitet in v modulacijah znotraj določene glasbene oblike. Tonalitete so namreč "preproste" z manj predznaki $(C, D, F, G, B, a$, $d$, g), skladatelj le redko poseže po tistih z več predznaki. Dosleden je seveda pri zaključnih akordih, ki so vedno tonični in tako potrjujejo osnovno tonaliteto skladbe. Le nekoliko bolj inovativen je $\mathrm{v}$ uvodnih akordskih zvezah, ki v posameznih primerih le niso tonične. Med njimi najbolj izstopajo začetni akordi skladbe Spomlad trka na duri (primer 12), ko prva akorda kot stranski VII. na II. stopnjo $F$-dura varljivo napovesta $g$ mol, vendar se ne razrešita po pričakovanju, saj vodi alteracija tona es $\mathrm{v} e$ neposredno $\mathrm{v}$ dominantni kvintsekstakord osnovne tonalitete.

primer 12

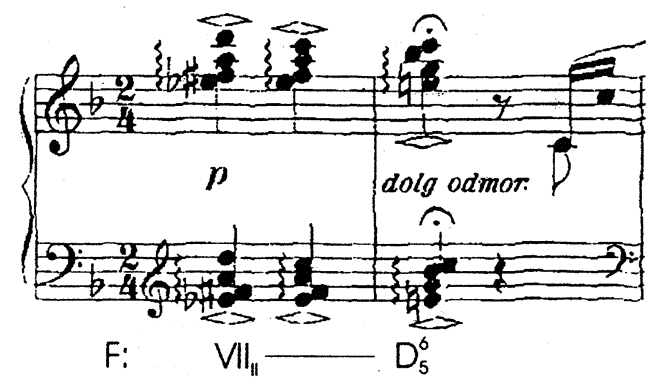

Večjo harmonsko pestrost, kontrast med posameznimi periodami ali večjimi deli glasbene oblike ter napetost glasbenega toka doseže Krek z modulacijami, ki so največkrat diatonične, redko pa kromatične (na primer Slovanski capriccietto; Veselo obvestilo, op. 56; Bagatela; Jesen; Jugoslovanski ples I, II, op. 59/1,2). Število tonalnih sprememb navadno narekuje dolžina skladbe, saj zahtevajo daljše, kompleksnejše skladbe več modulacijskih sprememb. Zaradi tega dejstva je zato zanimiva 44-taktna skladba Spomladni dan, v kateri skladatelj niti enkrat ne zapusti osnovne tonalitete $D$-dura, kar pa ne vodi v monotonost harmonskega toka. Že takoj $\mathrm{v}$ začetku je na primer alteriran tonični akord $\mathrm{v}$ spremljavi (primer 13), pa tudi v nadaljevanju so alterirani akordi razmeroma pogosti. Prav ta dualizem, enovitost na eni strani ter bogata kromatika na drugi, je vodilo tega glasbenega dela in melodičnega poteka znotraj njega.

primer 13

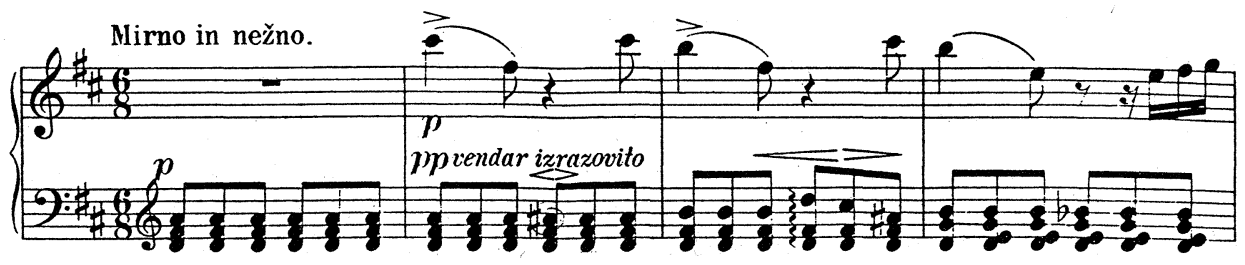

Mesta tonalitetnih sprememb so predvidena in nastopijo na pričakovanih mestih znotraj glasbene oblike. Modulacije so jasne in logične, hipne ali pripravljene - slednje navadno $\mathrm{v}$ taktih na prehodu $\mathrm{v}$ večji, kontrasten del skladbe, kjer se tonaliteti (enega in drugega dela) največkrat prežemata, izmenjujeta in dopolnjujeta, sočasnost obeh pa "dokazujeta" oba vodilna tona.

Krekovo ustvarjanje vsekakor obvladuje tonalna hierarhija. Funkcije akordov so jasne in enopomenske. Analiza del razkriva jasno harmonsko shemo, v kateri največkrat prevladujejo glavne lestvične stopnje, funkcionalno nejasnih akordov ni. Znotraj take 
harmonske strukture pa se vendarle kaže kompozicijski prijem, ki izpričuje ideje novejših stilnih naziranj. Te ideje pravzaprav ne presegajo skladateljske prakse prve polovice 19. stoletja, a vseeno izstopajo iz skladateljevega klasicistično naravnanega koncepta. Kažejo se v pogosti uporabi stranskih dominant, stranskih sedmih stopenj ter mediantike, ki pomenijo trenutne izmike iz osnovne tonalitete in kot take bogatijo harmonski, $s$ tem pa tudi zvočni prostor. Prav tako vlogo imajo tudi harmonsko tuji toni ter diatonične (in le izjemoma kromatične) alteracije različnih, le redko tudi toničnih stopenj. Ne eni ne drugi pa ne pomenijo večjega odstopanja, diatonično strukturo le zakrivajo in hkrati tonsko barvajo. Prav zato so skladbe v samem zvenenju pogosto nejasne.

Stabilnost in jasnost osnovne tonalitete slabijo tudi bitonalitetni takti, ki ne pomenijo vedno zgolj pasusov, grajenih na pedalnih toniki in dominanti. Bitonalitetnost lahko nastopi tudi zaradi prostega vodenja linij, vendar pa latentne harmonije posameznih glasov med seboj nikoli niso bolj oddaljene. Pri tem je večglasna struktura močno odvisna od postavitve tonov - harmonija celotne vertikale zveni toliko bolj enovito, kolikor bolj so toni posameznih akordov med seboj pomešani: na primer Slovanski capriccio (primer 14).

primer 14

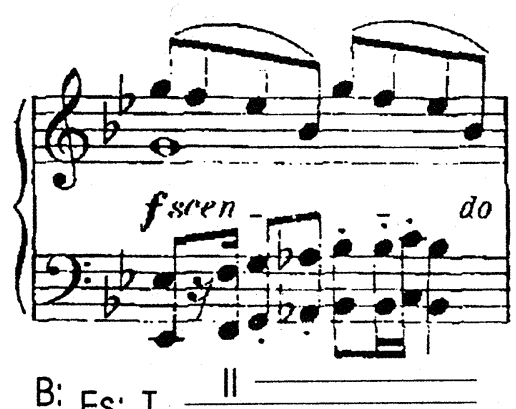

Rezultat interakcije med melodiko in harmonijo je glasbena oblika, ki pri Kreku ne zapušča shematične zaokroženosti in doslednosti oblikovnega razvoja. Težnja za oblikovno popolnostjo je skladatelju prinesla celo očitek formalizma. Res je sicer pomenila Kreku glasbena oblika dovršenost kompozicijske tehnike, tako da je oblikovnemu postopku nemalokrat podredil druge glasbene parametre. Kljub temu pa skladateljev oblikovni proces ni le slepo zasledovanje $\mathrm{v}$ naprej določene sheme, pač pa organski proces razvijanja, vkoreninjen $\mathrm{v}$ klasicistični oblikovni estetiki. Oblikotvorno vlogo imajo $\mathrm{v}$ prvi vrsti melodika in ritem (torej motivično-tematsko delo) ter harmonija, $\mathrm{v}$ širšem planu pa tudi tempo. Oblikovanje pa vedno temelji na osrednjem estetskem principu: edinost v raznoterosti. Kontrast je namreč gonilo razvoja celote in vodi $\mathrm{k}$ sintezi različnih elementov.

Znotraj takega postopka oblikovanja prevladujejo velike tridelne pesemske oblike (A-B-A), večinoma preproste in z dobesedno ponovitvijo reprize. Prvi A-del je navadno oblikovan kot tridelna pesemska oblika $a-b-a$, ki predstavlja tematsko homogeno zaokroženo celoto. Srednja (b) perioda namreč ne prinese nove, kontrastne motivike, ampak najpogosteje temelji na tematskem gradivu osnovne periode. Reprizna perioda je lako dobesedna ponovitev ali pa le minimalno variirana, največkrat v zaključnih taktih, da bi prepričljivo zaključila glasbeni del. Nekatere skladbe pa v oblikovanju prvih delov 
odstopajo od prevladujočega oblikovnega postopka. Najpogostejša pri tem je ponovitev obeh period $\|: a:\|\|: b:\|$, ki pomeni $v$ Krekovem klavirskem opusu sicer redek primer dvodelnega oblikovanja A-dela. Izjemoma pa je moč zaslediti še razvojno oblikovanje variacijskega načela.

Tudi srednji B-del je navadno zasnovan kot tridelna $a-b-a$ ali dvodelna $a-b$ pesemska oblika. Pogosteje je zaokrožena celota, neredko pa ga $\mathrm{z}$ reprizo povezujejo prehodni modulacijski takti; posledično je konec odprt, trdne zaključne kadence, ki bi zaokrožala celoto, zato ni. Tako kot v oblikovanju A-delov je skladatelj tudi v srednjih B-delih uporabil še drugačne oblikovne postopke, čeprav bolj redko. Najpogostejša med njimi je epizodna gradnja, ki temelji na eni, navadno (dosledno ali nedosledno) ponovljeni periodi $\|: a:\|$.

Skladbe v Krekovem klavirskem opusu so torej bolj ali manj enovito oblikovane. Le redke so take, ki odstopajo od prevladujočega modela. To so lahko krajša glasbena dela, ki ne dosežejo dimenzij velikih oblik. Členjene so v periode, navadno tri $(a-b-a)$, pri čemer je srednja vsaj minimalno kontrastna osnovni. Nikoli pa ne prinese povsem nove, kontrastne motivike, zato je glasbena oblika bolj kot ne homogena. Nekatere oblike $\mathrm{v}$ opusu izkazujejo monotematsko gradnjo v smislu variacijskega ponavljanja ali razvijanja tematskega gradiva. Pravi pomen teme $z$ variacijami pa ima le ena skladba: $I z$ naših logov III, op. 55/3, v kateri je v prvi variaciji tema postavljena v spodnji glas in še imitacijsko ponovljena, $\mathrm{v}$ drugi pa transponirana oktavo višje in skrita $\mathrm{v}$ dvaintridesetinskem pasažnem gibanju razloženih akordov. $V$ daljših glasbenih oblikah je izjemoma moč zaslediti refrenski način oblikovanja, in sicer v skladbah Valse romantique, op. 46 in Valse rurale, op. 44, pri obeh pa ima vlogo refrena začetni A-del.

Tudi pri oblikah, ki od velike tridelne pesemske oblike odstopajo, tako ne gre za odmik od tradicionalnega. Poglobljenost v formi je sicer iz skladbe v skladbo večja, a ostaja skladatelj v oblikovanju glasbenega gradiva vseskozi dosleden. Romantični izraz namreč nikoli ne doseže takih razsežnosti, da bi mu moral prilagajati oblikovni proces in ga s tem (vsaj delno) oslabiti.

V klavirskem opusu izstopata primera Sanjarije, op. 43/1 in Sarabande, op. 43/2, ki izpričujeta skladateljevo navezanost na baročno glasbo in še posebej na Bacha. Baročni vpliv je sicer v Krekovih klavirskih delih neizrazit, vendar ga je skladatelj poudaril v svojih spisih v Novih akordih ${ }^{6}$. Omenjeni skladbi pomenita uspešen poskus združitve (2-delne) baročne suite $\mathrm{z}$ novejšimi naziranji, izraženimi $\mathrm{v}$ harmonskem in melodičnem poteku dela. Sorodnost je najbolj izrazita $v$ monotematski strukturi, medtem ko je tonalni koncept bolj svoboden $-\mathrm{v}$ njem namreč ni izrazita dominantna sorodnost tonalitet posameznih delov skladbe, ki je značilna $\mathrm{v}$ baročni obliki.

Vsako glasbeno delo ima neko značilno celoto, bodisi motiv ali motivično dvotaktje, $s$ pomočjo katere skladatelj tvori stavke, periode in nenazadnje tudi večje dele skladb. Delo z motivom je pri Kreku raznovrstno, pri tem pa prevladuje njegovo variiranje. Le-to je v prvi vrsti melodičnega značaja, saj lahko tako skladatelj najbolj učinkovito razvija melodični potek. Zaznamujejo ga vrinjeni harmonsko tuji toni ali toni, ki nimajo vloge okraska, pač pa razširjajo melodično linijo. Pri melodičnih spremembah gre lahko za variirano intervalsko gibanje, pogosto pa je spremenjena tudi smer melodičnega poteka.

\footnotetext{
${ }^{6}$ Bachov vpliv na Kreka je v prvi vrsti razviden iz skladateljevih razmišljanj o glasbi, šele nato tudi v glasbi sami. V obeh primerih pa mu je glasba baročnega skladatelja nudila tisto "tehnično dovršenost", za katero je stremel in katere pomembnost ter nujnost je vseskozi poudarjal.
} 
Dosledno sekvenčno ponavljanje je redko; zasledimo ga le v Sarabandi, op. 43/2. Pogosteje je imitacijsko oblikovanje, še posebej v razvojnih in prehodnih delih. Imitacijske ponovitve so navadno svobodne, predvsem melodično variirane. Prav tako redka je stroga imitacija, torej kanon, katero skladatelj uporabi v skladbah Iz naših logov I, op. 55/1 in Domače epizode I, op. 29/1 (primer 15), in sicer le znotraj posamezne periode, ne pa skozi celo skladbo.

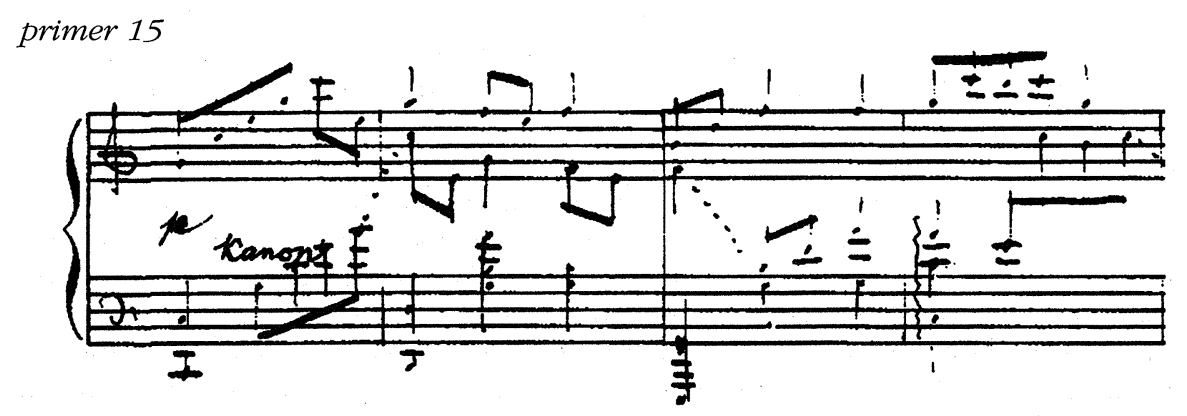

Motiv je lahko tudi ritmično spremenjen. Tak postopek je sicer redek, hkrati pa gre vedno tudi za melodično variiranje. Zato so spremembe majhne, da je ohranjen značaj motivike. V Romanci, op. 47/1 je moč zaslediti variiranje s pomočjo diminucije, lahko pa je enakomerno gibanje občasno obogateno s punktiranim ritmom (kot na primer v Jugoslovanskem plesu VI, op. 61/6 ali Iz potne torbe I, op. 38/1).

Znotraj takšne ali drugačne glasbene oblike pa je značilno tudi delo s kontrasti, ki sicer učinkujejo, a ne pomenijo več kot nujno sredstvo v postopku oblikovanja. Posamezni deli glasbene oblike med seboj namreč kontrastirajo toliko, da upravičijo in utemeljijo novo tematiko v skladbi. Sicer pa skladatelj uporablja ustaljene postopke spreminjanja glasbenega toka: največkrat prinese kontrast nova motivika, lahko še podprta $s$ spremenjenim tempom in drugačno zasnovo. Če je prvi del hiter, melodika vedra in ritem soglasno s tem lahko tudi bolj pester in diferenciran, je drugi del pogosto počasnejši, melodika umirjeno spevna, njej prilagojen pa je tudi ritem. Tako delo s kontrasti je $v$ Krekovem opusu najpogostejše in tudi najučinkovitejše. Le izjemoma je v B-delu skladbe spremenjen tudi taktov način, ki pomeni bistveno spremembo in kontrast utripa glasbenega toka. Pri Kreku edini tak primer zasledimo v skladbi Domače eipzode II, op. 29/2, v kateri je taktov način A-dela 2/4, B-dela pa 3/8.

Kontrast je torej utemeljen $\mathrm{v}$ spremenjenem izrazu, vedno pa tudi $\mathrm{v}$ novi tonaliteti. Slednja navadno ne pomeni večje oddaljenosti od osnovne tonalitete skladbe, zato tudi ni izstopajoč dejavnik v spremembi glasbenega poteka: najpogostejša med njima je dominantna sorodnost, neredko pa tudi terčno oziroma mediantno razmerje. Le izjemoma sta tonaliteti med seboj bolj oddaljeni: Jugoslovanski ples I, op. 56/1 (B-dur - A-dur); Iz naših logov II, op. 55/2 (G-dur - As-dur). Prav zato je vprašanje kontrastnosti glede na tonalni preskok relativno, ima pa nedvomno pomembno vlogo v oblikovanju celote.

Glasbeni kontrast kot tak ne doseže večjih dimenzij, skladatelj ga včasih tudi namerno zakrije, posledično pa navidezno razblini. Kontrastnost med posameznimi deli je lahko tudi prikrita, ko skladatelj $\mathrm{v}$ reprizno periodo B-dela uvede značilne melodične postope (Iz potne torbe $V$, op. 38/5) ali kar cela motivična dvotaktja (Iz naših logov I, op. 55/1 - primer 16) A-dela. Tako zaključna perioda srednjega hkrati napoveduje tudi uvodno periodo repriznega dela. 
primer 16

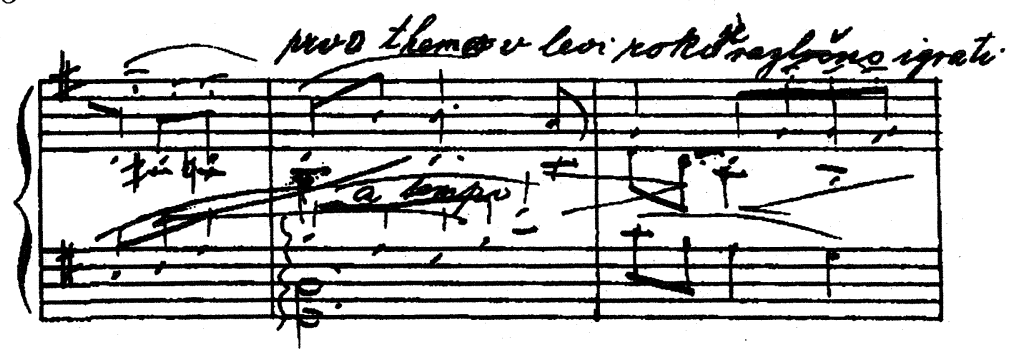

Učinkovitost kontrasta pa je izjemoma zmanjšana tudi zaradi enovite spremljave, ki poteka od začetka do konca skladbe Iz naših logov III, op. 55/3 (primer 17). Zato pa si $\mathrm{A}$ in B-del omenjene skladbe zaradi enovite spremljave toliko bolj konrastirata $\mathrm{v}$ izrazu melodike, prav tako pa tudi $\mathrm{v}$ tempu (hitro : mirno). Skladatelj mora razlike namreč še posebej poudariti, da bi upravičil in hkrati zakril enovitost spremljevalnega poteka, ki je tudi ritmično zelo izrazen, poudarjen s punktirano celico. Le tako se lahko izogne morebitni enoličnosti glasbenega dela.

primer 17

A-del, perioda a

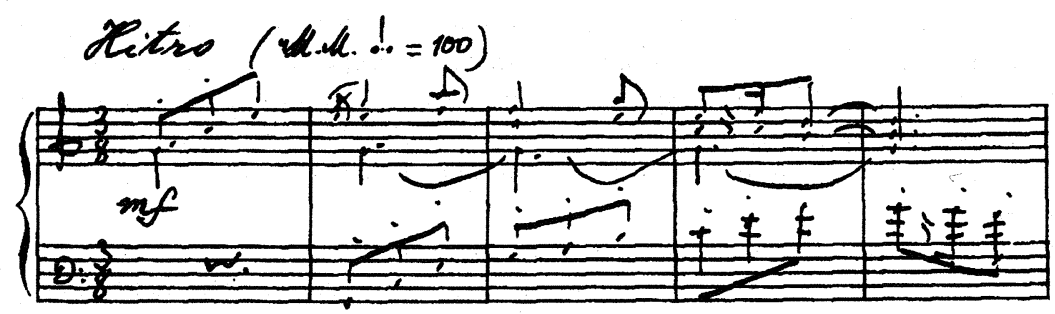

A-del, perioda $b$

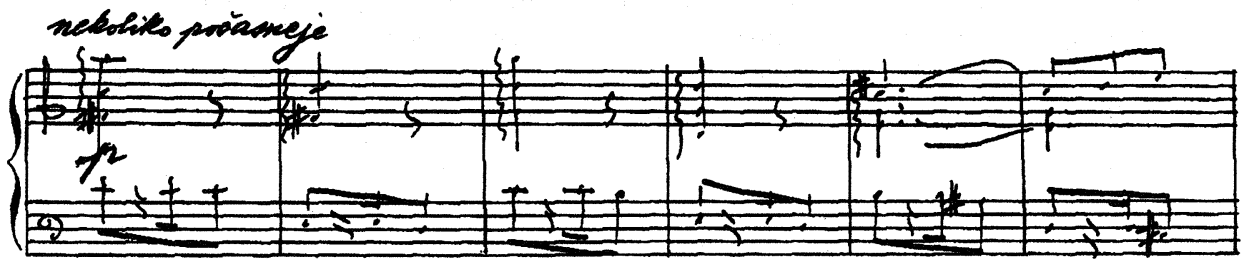

B-del

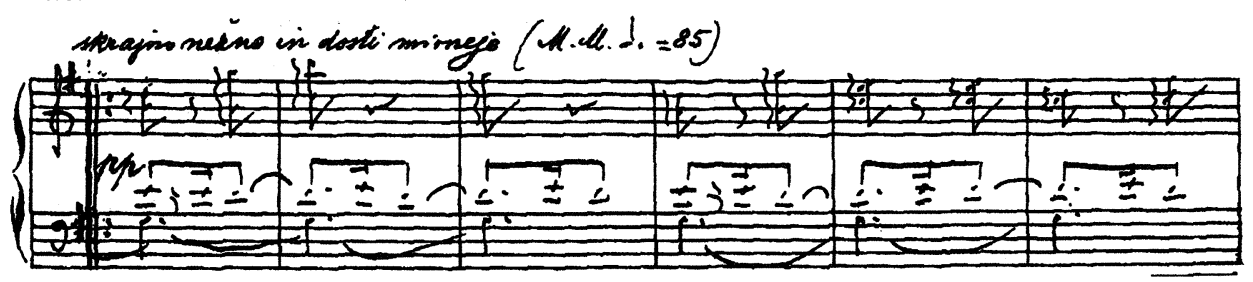


Členjene forme prinesejo $\mathrm{v}$ širšem planu tudi spremembe $\mathrm{v}$ tempu, ki največkrat sovpadajo $s$ kadenčnim gibanjem in periodično gradnjo, da bi še potrdile zaokroženost nekega glasbenega odseka znotraj celote. Ritardando v zaključku posameznega dela ali odseka skladbe ter še posebno v zaključnih taktih je skoraj obvezujoč; pogosto pa zaokroža tudi posamezno periodo in tako hkrati napoveduje tisto, ki sledi. Če je v zaporedju več period, je tempo med vsako posamezno najpogosteje upočasnjen. Taka sprememba tempa je neredko še poudarjena $z$ diminuendom, predvsem $v$ finalnih taktih, le izjemoma pa s crescendom. Slednji nastopi največkrat kot priprava na reprizno ponovitev osnovne periode in tako stopnjuje napetost.

Manj pogost je $\mathrm{v}$ Krekovih klavriskih delih accelerando, ki nastopi predvsem v razvojnih delih skladbe, ko stopnjuje učinkovitost crescenda. Nenavadno v opusu pa je oblikovanje A-dela skladbe Domače epizode II, op. 29/2, v kateri vodi daljši accellerando $\mathrm{k}$ reprizni ponovitvi $a$ periode; le-ta pa se nato ne povrne v prvotni tempo, ampak jo zaznamuje nov, hitrejši tempo, s katerim skladba zaključi (osnovna perioda $\delta=116$, reprizna ponovitev $\delta=138$ ).

Tako melodika kot harmonija, pa tudi oblikotvorni postopek izpričujejejo torej nihanje skladatelja med klasicistično in romantično estetiko, hkrati pa že kažejo novejša skladateljska naziranja, ki v Krekovem klavirskem opusu nikoli niso bila do konca uresničena. Tudi v poznejših delih, $v$ katerih sicer poglobi tako izraz kot formo, ostaja Krek kot skladatelj navezan na tradicijo in, kljub težnji po naprednem, slogovno isti, a iz skladbe v skladbo umetniško bolj zrel. Klavirski opus je zato kljub daljšemu časovnemu obdobju, ki ga obsega, bolj ali manj enovit in ne preseže skladateljske prakse 19. stoletja. V Krekovi glasbi se kaže predvsem vpliv Schuberta in Mendelssohna, tudi Schumanna in Brahmsa, le izjemoma Chopina. Zgledi so bili številni, a za Kreka bolj ali manj nedosegljivi. Kromatizem glasbenega poteka sicer nakaže tudi Krekovo navezanost na glasbo poznega 19. stoletja, a le-te nikoli ne doseže in tako ne uresniči naprednejših idej lastnih razmišljanj.

Zato je bil Krek kot skladatelj in teoretik aktualen predvsem v času Novih akordov, a so že takrat nekateri sodobniki $z$ naprednejšimi deli njegov skladateljski prispevek pogosto zasenčili. Analiza del sicer pokaže skladateljevo navezanost na klasicistično in (zgodnje)romantično tradicijo, so pa zato njegove teoretske misli in ideje vplivale na skladateljski element tistega časa ter na takratno glasbeno žvljenje na Slovenskem nasploh. Z Novimi akordi je tako korenito posegel $v$ glasbeno življenje na Slovenskem in postavil temelje "nove" ustvarjalne dobe. Zato mu vsekakor velja pripisati pomembno vlogo v razvoju slovenske, tudi in še posebej klavirske glasbe. 